\title{
(2) OPEN ACCESS \\ Development of ASAS quality standards to improve the quality of health and care services for patients with axial spondyloarthritis
}

\author{
Uta Kiltz (1) , ${ }^{1}$ Robert B M Landewé, ${ }^{2,3}$ Désirée van der Heijde (i), ${ }^{4}$ Martin Rudwaleit, ${ }^{5}$ \\ Michael H Weisman, ${ }^{6}$ Nurullah Akkoc, ${ }^{7}$ Annelies Boonen, ${ }^{8,9}$ Jan Brandt, ${ }^{10}$ \\ Philippe Carron, ${ }^{11,12}$ Maxime Dougados, ${ }^{13,14}$ Laure Gossec (1) , ${ }^{15,16}$ Merryn Jongkees, ${ }^{17}$ \\ Pedro M Machado (1) , ${ }^{18,19}$ Helena Marzo-Ortega, ${ }^{20}$ Anna Molto (1) , ${ }^{14,21}$ \\ Victoria Navarro-Compán, ${ }^{22}$ Karin Niederman, ${ }^{23}$ Percival Degrava Sampaio-Barros, ${ }^{24}$ \\ Gleb Slobodin ${ }^{25}$ Filip E Van den Bosch, ${ }^{12,26}$ Astrid van Tubergen, ${ }^{8}$ Salima van Weely, ${ }^{27}$ \\ Dieter Wiek, ${ }^{28}$ Juergen Braun ${ }^{1}$
}

\section{Handling editor Josef $S$ \\ Smolen}

- Additional material is published online only. To view please visit the journal online (http://dx.doi.org/10.1136/ annrheumdis-2019-216034).

For numbered affiliations see end of article.

\section{Correspondence to}

Dr Uta Kiltz, Rheumatology, Rheumazentrum Ruhrgebiet, Ruhr-University Bochum, Herne 44801, Germany; uta.kiltz@elisabethgruppe.de

Received 17 July 2019 Revised 26 September 2019 Accepted 28 September 2019 Published Online First 11 October 2019
Check for updates

(C) Author(s) (or their employer(s)) 2020. Re-use permitted under CC BY-NC. No commercial re-use. See rights and permissions. Published by BMJ.

\section{To cite: Kiltz $U$,} Landewé RBM, van der Heijde D, et al. Ann Rheum Dis

2020:79:193-201.

\section{ABSTRACT:}

Objectives The Assessment of SpondyloArthritis International Society (ASAS) aimed to develop a set of quality standards (QS) to help improve the quality of healthcare provided to adult patients affected by axial spondyloarthritis (axSpA) worldwide.

Methods An ASAS task force developed a set of QS using a stepwise approach. First, key areas for quality improvement were identified, discussed, rated and agreed on. Thereafter, areas were prioritised and statements for the most important key areas were phrased on consensus. Appropriate quality measures were defined to allow quantification of the QS at the community level.

Results The ASAS task force, consisting of 20 rheumatologists, two physiotherapists and two patients, selected and proposed 34 potential key areas for quality improvement which were then commented by 140 ASAS members and patients. Within that process three new key areas came up, which led to a re-evaluation of all 37 key areas by 120 ASAS members and patients. Five key areas were identified as most important to determine quality of care: referral including rapid access, rheumatology assessment, treatment, education/self-management and comorbidities. Finally, nine QS were agreed on and endorsed by the whole ASAS membership.

Conclusions ASAS successfully developed the first set of QS to help improving healthcare for adult patients with axSpA. Even though it may currently not be realistic to achieve the QS in all healthcare systems, they provide high-quality of care framework for patients with axSpA that should be aimed for.

\section{INTRODUCTION}

Axial spondyloarthritis (axSpA) is a chronic inflammatory disease of the axial skeleton with inflammatory back pain as the major symptom, and spinal/sacroiliac joint inflammation and new bone formation as the most pathognomonic features. ${ }^{1}$ There is wide variation in the delivery and quality of healthcare for patients with axSpA. The mission of the Assessment of SpondyloArthritis International Society (ASAS) as an international group of

\section{Key messages}

What is already known about this subject?

- Wide variation in the delivery and quality of healthcare for patients with axial spondyloarthritis (axSpA) exists.

- Provision of measurable constructs can help to identify key gaps in the current provision care at the community level

- Quality assessment tools have been published for several rheumatological conditions; none relate specifically to patients with axSpA.

What does this study add?

- Assessment of SpondyloArthritis International Society (ASAS) developed the first set of quality standards to help improving health care for adult patients with axSpA.

- Quality standards have been formulated for key area of referral, rheumatology assessment, treatment, education/self-management and comorbidities.

How might this impact on clinical practice or future developments?

- ASAS quality standards provide high-quality of care framework for patients with axSpA intending to help organisations improve quality of care and to monitor service improvements.

- ASAS quality standards are achievable in daily care in an optimised situation and intend to minimise variation in quality of care.

experts in the field of spondyloarthritis $(\mathrm{SpA})$ is to support and promote the study of axial and peripheral $\mathrm{SpA}$, to increase awareness and early diagnosis of the disease, to develop and validate assessment tools, and to evaluate treatment modalities in order to promote clinical research with the ultimate goal to improve outcome of the disease (ASAS website: www.asas-group.org). Several unmet needs such as delayed diagnosis and restricted access to treatment have been described in many countries 
worldwide. ${ }^{2} 3$ These and other gaps in current care provision prompted ASAS in 2016 to start developing a set of quality standards (ASAS-QS) to help optimise access, treatment and patient outcomes in axSpA. Although the diagnostic delay has somewhat decreased in recent years, this is still significant when compared with rheumatoid or psoriatic arthritis. ${ }^{45}$ Furthermore, the availability and quality of health and care provision across rheumatological diseases varies worldwide due to different economic and political realities and healthcare systems. ${ }^{3}$ Thus, assessing the quality of care provided to patients with axSpA is important not only to patients and physicians, but also to providers and purchasers of healthcare. ${ }^{6}$

There is no agreed methodology to quantify quality of care. According to the US Institute of Medicine quality measures assess "the degree to which health services for individuals and populations increase the likelihood of desired health outcomes and are consistent with current professional knowledge". ${ }^{7}$ Different validated measurement sets such as quality indicators, performance measures or quality standards (QS) have been suggested to establish measurable constructs. ${ }^{89}$ To date, quality assessment tools have been published for several rheumatological conditions like inflammatory arthritis, rheumatoid arthritis and gout, ${ }^{10-12}$ but none of these relate specifically to patients with axSpA.

The UK based National Institute of Clinical Excellence (NICE) has a long trajectory of developing QS defined as a set of statements to help improve quality of health and care services and very recently published a quality assessment tool for patients with axSpA. ${ }^{13}$ The different measurement sets relate to measurable aspects of healthcare, and in contrast to guidelines or recommendations, the measurement sets do not reflect all stages and levels of disease status.

ASAS decided to choose QS as quality assessment tool, based on the methodology used by NICE. NICE specifies QS should be developed to cover areas where there is variation of care and identify resources and processes which need to be optimised in order to achieve quality improvement. ${ }^{14} \mathrm{QS}$ offer the opportunity to define measurable constructs which can be operationalised in structural or process related characteristics of healthcare as defined by Donabedian. ${ }^{15}$ Donabedian's classical theoretical framework for measuring healthcare quality includes three related categories of which the first two, that is, structures (innate characteristics of providers and the system), and processes (what healthcare providers do in delivering care), influence the third category: outcomes (what happens to patients, particularly with respect to their health).

Improvement in quality of care should focus on those areas in which there is evidence of variation in the delivery of care. Those key areas for quality improvement should identify key requirements for high-quality care or service provision that are expected to contribute to improving the experience of care or services as well as their safety and effectiveness. However, topics have to be balanced between ideal settings and actual clinical practice settings and QS should therefore describe enhanced practice, which is aspirational but achievable in daily care.

Thus, our objective was to develop international QS to improve the quality of care for adult patients with axSpA by identification of key gaps in the current provision care at the community level.

\section{METHOD}

First, in order to operate its QS programme, ASAS nominated two groups: a Steering Committee (JB, UK, RL, MR, DvdH, MW) and a QS group tasked with the development of an ASAS-QS set.
This QS group was formed by ASAS members proposed by the ASAS Executive Committee, based on their clinical and research experience in outcome and management of SpA. The ASAS-QS group decided to (1) invite additional patients and healthcare professionals in order to meet priorities and to guarantee representativeness of the group and (2) to utilise the pre-existing ASAS recommendations for early referral for patients with a suspicion of axSpA and ASAS recommendations for the management of axSpA as scientific key source guidance. ${ }^{16} 17$ All ASAS members are actively involved in scientific projects and ASAS members are referred here as 'ASAS community'.

The ASAS-QS group used a stepwise approach to develop a disease-specific set of QS for adult patients with axSpA (figure 1). ASAS decided to base any subsequent methodological approach on NICE quality standard process guide excluding any reference or involvement to payers of the health system as this differs widely across countries. ${ }^{14}$ In order to meet stakeholder priorities, ASAS members were asked twice to identify key areas for quality improvement in an attempt to understand all relevant medical needs and gaps at a national level.

Each quality standard consists of two components: a quality statement and a quality measure. A quality standard set addresses key areas for quality of care improvement by providing specific, clear, concise, and measurable statements that are derived from evidence-based guidance. Each quality statement is accompanied by a quality measure which is meant to quantify the quality of care or service provision specified in the statement by providing a numerator and a denominator. Further, each quality standard is accompanied by a rationale providing the scientific evidence and the guidance and definitions of the terms used for each specific quality statement.

The following steps were undertaken to develop the ASAS-QS for adult patients with axSpA:

1. Provisional list of key areas for quality improvement: ASASQS group members convened at a face-to-face 1-day meeting to set up the remit of the work in Berlin in January 2016. After an extensive open discussion, it was decided to use a stepwise approach by starting with the identification of possible key areas for quality improvement. This should be areas in which variation in care exists but which can be improved and which are measurable and achievable. Key areas for quality improvement were grouped into the categories structure, process and outcomes to help guiding the subsequent steps.

2. Evaluation of the provisional list of key areas for quality improvement: During summer 2016, ASAS members and patient representatives were invited via a web-based survey to comment on this provisional list and to identify additional key areas for quality improvement not mentioned before in the provisional list. Patient representatives were invited via the national patient organisation. Participants were asked to agree or disagree to each single QS item. ASAS-QS group agreed that a key area for quality improvement would be considered as important when $\geq 25 \%$ of the participantsindependent of being patient or professional-agreed to the key areas for quality improvement. Participants received background information on the definition and process development of QS prior to starting the survey to reduce probability of misinterpretation or misunderstanding. ASAS-QS group and two patient representatives met to discuss the findings of the web-based survey in a face-to-face meeting (September 2016).

3. Prioritisation of key areas for quality improvement: All participants who completed step 2 were then invited to actively contribute to the development process and to comment on 


\begin{tabular}{|c|c|c|c|c|}
\hline \multicolumn{5}{|c|}{ Non-rheumatology Care } \\
\hline $\begin{array}{l}\text { Clinical } \\
\text { symptoms }\end{array}$ & \multicolumn{4}{|c|}{$\begin{array}{l}\text { QS 1Referral: People with suspicion of axial SpA are referred to a } \\
\text { rheumatologist for diagnostic assessment within } 3 \text { working days. }\end{array}$} \\
\hline \multicolumn{5}{|c|}{ Rheumatology care } \\
\hline $\begin{array}{c}\text { Diagnosis/ } \\
\text { Differential- } \\
\text { diagnosis }\end{array}$ & \multicolumn{2}{|c|}{$\begin{array}{l}\text { QS 2: Time to Specialist } \\
\text { People with suspicion of axial } \\
\text { SpA are assessed by a } \\
\text { rheumatologist within } 3 \text { weeks } \\
\text { after referral. }\end{array}$} & \multicolumn{2}{|c|}{$\begin{array}{l}\text { QS 3: Assessment } \\
\text { People with suspected axial SpA } \\
\text { have their diagnostic work-up } \\
\text { completed within } 2 \text { months. }\end{array}$} \\
\hline Treatment & $\begin{array}{l}\frac{\text { QS 4: Monitoring }}{\text { Disease Activity }} \\
\text { Disease activity of } \\
\text { people with axial SpA } \\
\text { is monitored under the } \\
\text { supervision of a } \\
\text { rheumatologist with } \\
\text { validated composite } \\
\text { scores at least twice a } \\
\text { year. }\end{array}$ & $\begin{array}{r}\text { QS } \\
\text { In pe } \\
\text { Sp } \\
\text { dis } \\
\text { C } \\
\text { ther } \\
\text { es } \\
\end{array}$ & $\begin{array}{l}\text { Disease } \\
\text { ontrol } \\
\text { e with axial } \\
\text { nd active } \\
\text { e despite } \\
\text { entional } \\
\text { treatment } \\
\text { ation with } \\
\text { ogics is } \\
\text { ussed. }\end{array}$ & $\begin{array}{l}\frac{\text { QS 6: Non }}{\text { pharmacological }} \\
\text { Treatment } \\
\text { People with axial } \\
\text { SpA are informed } \\
\text { about the benefits } \\
\text { of regular } \\
\text { exercise. }\end{array}$ \\
\hline Management & $\begin{array}{l}\text { QS 7: Education and } \\
\text { Self-management } \\
\text { People with axial SpA } \\
\text { are offered education } \\
\text { on the disease } \\
\text { including self- } \\
\text { management within } \\
\text { two months of } \\
\text { diagnosis. }\end{array}$ & $\begin{array}{l}\text { QS 8 } \\
\text { Pati } \\
\text { Spf } \\
\text { flar } \\
\text { dru } \\
\text { eff } \\
\text { ad } \\
\text { wo } \\
\text { co } \\
\text { rhe }\end{array}$ & $\begin{array}{l}\text { apid Access } \\
\text { s with axial } \\
\text { dd disease } \\
\text { r possibly } \\
\text { lated side } \\
\text { s receive } \\
\text { within } 2 \\
\text { g days of } \\
\text { icting the } \\
\text { latologist. }\end{array}$ & $\begin{array}{c}\frac{\text { QS 9: Annual }}{\text { Review }} \\
\text { People with axial } \\
\text { SpA have a } \\
\text { comprehensive } \\
\text { annual review by } \\
\text { the } \\
\text { rheumatologist. }\end{array}$ \\
\hline
\end{tabular}

Figure 1 Summary of the nine Assessment of SpondyloArthritis International Society quality statements. SpA, spondyloarthritis.

the complete list of key areas for quality improvement via a web-based survey. They received background information on QS prior to starting the survey. Participants were then asked to prioritise key areas for quality improvement by indicating level of importance on a numerical rating scale (NRS) 0 (not important at all) to 10 (very important). A threshold of $75 \%$ of participants reaching $\geq 8$ on NRS-independent of being patient or professional-was considered as reflecting an important key area for quality improvement. As there was no guidance for a cut-off in the literature, the steering group decided to use a strict cut-off for agreement to ensure a select decisions made based on wide agreement.

4. Identification of final key areas for quality improvement: ASAS-QS members discussed in a 1-day meeting (January 2017) the further methodology. As part of this process, the most important key areas for quality improvement from step 3 were regrouped into domains for which quality statements and measures should be developed. The ASAS-QS group was then asked to propose phrasing of important QS.

5. Phrasing of QS: ASAS-QS members drafted a statement, rationale and measure for selected key areas in a 1-day meeting (January 2018). If necessary, aspects were phrased in more than one statement. Phrasing of the QS was influenced by proposals of the ASAS community.
6. Voting on ASAS-QS: ASAS-QS group presented the ASAS-QS set to the ASAS community in January 2018 and discussed the content, applicability and implementation of the final ASAS-QS set. Subsequent to the meeting the ASAS members were again asked to give the level of agreement on an NRS 0 (I do not agree at all) to 10 (I fully agree) in a web-based survey. A threshold of $75 \%$ of participants reaching $\geq 7$ on NRS was needed to be agreed by the ASAS community.

a. Re-evaluation on QS 1 and 2: QS 1 and 2 provoked disagreement and required further discussions. Therefore, the ASAS-QS group provided background information and education sessions on meaning and intention of QS and discussed rephrasing of final ASAS-QS set. ASAS members were invited in November 2018 to comment on QS 1 and 2 in a web-based survey by answering the following questions: "I agree to the phrasing of QS 1 (2, respectively) and do not wish a change of this quality statement". Participants who affirmed the question were asked to rate the level of agreement on an NRS 0 (I do not agree at all) to 10 (I fully agree). Participants who denied the question were asked to share thoughts about QS 1 (2, respectively) and to specify disagreement.

7. Endorsement by the ASAS membership: 'Pro' and 'con' arguments to QS 1 and 2 were exchanged during the annual 
ASAS meeting in January 2019 in Amsterdam. After extensive discussion, a simple vote for agreement/disagreement of QS 1 and 2 was taken from ASAS members.

\section{RESULTS}

The ASAS-QS group consists of 20 rheumatologists, two physiotherapists and two patient research partners.

1. Provisional list with key areas for quality improvement: The ASAS-QS group developed in January 2016 (Berlin) a list with 34 potential key areas for quality improvement (online supplementary file 1$)$. Key areas were grouped into the categories structure $(n=7)$, process $(n=23)$ and outcome $(n=4)$.

2. Evaluation of the provisional list of key areas for quality improvement: 140 participants (86 ASAS members and 42 axSpA patients from 10 countries (Belgium, France, Germany, Israel, the Netherlands, Portugal, Spain, Turkey, UK, USA), 12 participants did not provide demographics, see online supplementary file 2) evaluated the provisional list of key areas for quality improvement in summer 2016 via a webbased survey. Five new key areas for quality improvement were proposed (one item for the category structure (structural support for physiotherapist-led exercise), two items for the category process (extra-articular manifestation and assessment of current treatment), and two items for the category outcome (percentage of patients who improved in mobility as measured by physiotherapists tests and percentage of hospital admissions for complicated disease)). The rate of misunderstanding was low, in most cases $<5 \%$, except for comorbidities (8.6\%), morphometric assessment (26.4\%), corrective osteotomy (15.0\%), and total arthroplasty (13.6\%). All key areas for quality improvement initially proposed by the group reached the threshold of $25 \%$ agreement (mean agreement to the categories structure $83.8 \%$, process $79.5 \%$ and outcome $56.8 \%$. Agreement with each single key area is shown in online supplementary file 1 . The results of the survey were presented to the ASAS-QS group and two patient representatives at a meeting in Ghent in September 2016 where future steps regarding the prioritisation of key areas for quality improvement and content validity of possible QS were extensively discussed.

3. Prioritisation of key areas for quality improvement: In autumn 2016, 120 participants (86 physicians, 29 patients, five participants did not provide demographics, see online supplementary file 2) prioritised in a web-based survey 39 key areas for quality improvement, across three categories structure, process and outcome (see online supplementary file 2). Key areas were prioritised between 4.5 and 8.6 (see online supplementary file 1 ). Five key areas were rated as most important: timely diagnosis, documentation of diagnosis, patient information, assessment of disease activity, and assessment of infection risks when starting biologicals.

4. Identification of final key areas for quality improvement: ASAS-QS group met in January 2017 in Leeds and decided to omit the strict segmentation in structure, process and outcome and rather phrase QS which may cover more than one of the categories structure, process and outcome. ASAS QS grouped selected key areas into superordinate domains: referral including rapid access, rheumatology assessment, treatment, education including self-management and comorbidities. The ASAS community provided detailed proposals about phrasing of most important domains.

5. Phrasing of QS: the ASAS-QS group drafted nine QS for axSpA encompassing a statement and a rationale, in January
2018 in Lisbon (tables 1-3). Since the identified key areas represent domains which can be applied in a wide context, it was necessary to think about their application in different clinical settings leading to more than one QS for one key area. Phrasing of QS was influenced by proposals of the ASAS community from step 4. Statements were provided for aspects of referral and rapid access $(n=4)$, rheumatology assessment $(n=1)$, treatment $(n=2)$, education $(n=1)$ and comorbidities $(n=1)$. Whenever timelines were mentioned, timelines were developed by consensus within the ASAS-QS group. The timelines were not data driven and represent the 'aspirational but achievable' aspect of the ASAS-QS which are presumably related to different national perception.

6. Voting on ASAS-QS: the proposed ASAS-QS were presented to the membership at the annual ASAS meeting in Lisbon in January 2018. At this meeting, the ASAS community intensively discussed the content, applicability and implementation of the final ASAS-QS set. One item in particular, the timeframes given in QS 1 and 2 was a matter of debate. Subsequent, voting in August 2018 among 115 ASAS members showed (too) low agreement for QS 1 and 2, whereas agreement was substantially higher for QS 3-9 (tables 1-3).

a. Re-evaluation of the final set of ASAS-QS: During August and November 2018, the ASAS-QS group provided background information and education sessions on meaning and intention of QS in general to ASAS community. In November 2018, 73 ASAS members provided feedback to QS 1 and 2. Disagreement to QS 1 was raised by 24 members of the ASAS community (32.9\%) whereas agreement to QS 1 was stated by 49 members (67.1\%). Agreement was documented by a high value of mean level of agreement (NRS 8.1 (1.9), $\geq 7: 92.1 \%)$. Disagreement to QS 2 was raised by 18 members (25\%) whereas agreement to QS 2 was stated by 54 members (75\%) (one missing response). Agreement was documented by a high value of mean level of agreement (NRS 7.9 (1.9), $\geq 7: 87.1 \%$ ). Arguments for disagreement of QS 1 were based on defined timeframe of three working days ('unrealistic setting'), exertion of rheumatologists on decisions made in general practitioner (GP) area, and unclear definition of the term 'suspicion of axSpA'. Arguments for disagreement of QS 2 were based on the defined timeframe of 3 weeks and lack of possibility of rheumatologist to intervene with a centralised appointment system.

7. Endorsement: QS 1 and 2 were discussed at the ASAS annual meeting in Amsterdam in January 2019. After extensive discussion, it was decided not to change the initially proposed phrasing of QS 1 and 2 and 98 ASAS members voted to retain QS 1 and 2 unchanged (QS 1: 77 approval, 10 decline, 0 abstention; QS 2: 72 approval, 11 decline, four abstention) (table 1).

Quality measures were drafted after the wording of the quality statements was agreed by the ASAS-QS group. All quality measures related to processes are expressed as a numerator and a denominator to define a proportion (numerator/denominator) (tables 1-3).

\section{DISCUSSION}

ASAS successfully developed the first QS set for the improvement of the quality of health and care services provided to adults with axSpA. These QS include a clear description of high priority areas for quality improvement and monitoring. Significant differences in the availability and quality of healthcare may 
Table 1 Quality standards (QS) for axial spondyloarthritis, clinical symptoms and diagnosis

\begin{tabular}{|c|c|c|c|c|c|c|c|c|}
\hline No & Domain & Statement & Rationale & $\begin{array}{l}\text { Quality measure, } \\
\text { category structure }\end{array}$ & $\begin{array}{l}\text { Quality } \\
\text { measure, } \\
\text { category } \\
\text { process, } \\
\text { numerator }\end{array}$ & $\begin{array}{l}\text { Quality measure, } \\
\text { category } \\
\text { process, } \\
\text { denominator }\end{array}$ & $\begin{array}{l}\text { Level of } \\
\text { agreement, } \\
\text { NRS 0-10 }\end{array}$ & $\begin{array}{l}\text { Agreement } \\
\text { (NRS } \geq 7 \text { by } \\
75 \% \text { of ASAS } \\
\text { members) }\end{array}$ \\
\hline QS1 & Referral & $\begin{array}{l}\text { Patients with } \\
\text { suspicion of } \\
\text { axSpA are } \\
\text { referred to a } \\
\text { rheumatologist } \\
\text { for diagnostic } \\
\text { assessment } \\
\text { within three } \\
\text { working days }\end{array}$ & $\begin{array}{l}\text { When axSpA is suspected, ASAS } \\
\text { recommendations for the early } \\
\text { referral of patients with a clinical } \\
\text { suspicion of axSpA provide criteria } \\
\text { for deciding whether the patient } \\
\text { should be referred to rheumatology } \\
\text { for special diagnostic assessment. } \\
\text { AxSpA is often missed in non- } \\
\text { specialist settings, resulting in } \\
\text { substantial delays in diagnosis and } \\
\text { treatment. No single test has been } \\
\text { shown to have sufficient sensitivity } \\
\text { or specificity to diagnose axSpA. } \\
\text { Timeframe of three working days is } \\
\text { expert-driven intending to trigger } \\
\text { immediate referrals. }\end{array}$ & $\begin{array}{l}\text { Evidence of local } \\
\text { arrangements } \\
\text { (including local } \\
\text { arrangements to } \\
\text { raise awareness of } \\
\text { signs and symptoms } \\
\text { of axSpA) and } \\
\text { written protocols to } \\
\text { ensure that patients } \\
\text { with suspicion for } \\
\text { axSpA are referred to } \\
\text { rheumatology within } \\
\text { three working days. }\end{array}$ & $\begin{array}{l}\text { The number of } \\
\text { patients with } \\
\text { a suspicion } \\
\text { of axSpA that } \\
\text { is referred to } \\
\text { rheumatology } \\
\text { within three } \\
\text { working days. }\end{array}$ & $\begin{array}{l}\text { The number of } \\
\text { patients with } \\
\text { a suspicion of } \\
\text { axSpA. }\end{array}$ & $\begin{array}{l}6.0 \pm 3.1 \\
\text { second vote: } \\
88.5 \% \text {. }\end{array}$ & 47.8 \\
\hline QS2 & $\begin{array}{l}\text { Time to } \\
\text { specialist }\end{array}$ & $\begin{array}{l}\text { Patients with } \\
\text { suspicion of } \\
\text { axSpA are } \\
\text { assessed by a } \\
\text { rheumatologist } \\
\text { within } 3 \text { weeks } \\
\text { after referral }\end{array}$ & $\begin{array}{l}\text { Rapid referral of patients with } \\
\text { suspicion of axSpA is important to } \\
\text { avoid delay in diagnosis and increase } \\
\text { the likelihood of early treatment } \\
\text { initiation. A rheumatologist (which } \\
\text { implies the rheumatology team } \\
\text { including physicians, nurses, and } \\
\text { other health professionals) is able } \\
\text { to identify axial and peripheral } \\
\text { manifestations as well as extra- } \\
\text { articular manifestations and } \\
\text { comorbidities. Given the potentially } \\
\text { detrimental effects of delayed } \\
\text { diagnosis, patients with these } \\
\text { symptoms and signs are in need of } \\
\text { a first appointment within } 3 \text { weeks. } \\
\text { Timeframe is expert-driven intending } \\
\text { to trigger timely appointments. } \\
\text { Timeframe of } 3 \text { weeks refers to } \\
\text { a first appointment. Additional } \\
\text { examinations required for decision- } \\
\text { making process can follow after the } \\
\text { first appointment. }\end{array}$ & $\begin{array}{l}\text { Evidence of local } \\
\text { arrangements } \\
\text { including sufficient } \\
\text { number of } \\
\text { rheumatologists to } \\
\text { ensure that patients } \\
\text { with suspicion of } \\
\text { axSpA can be seen } \\
\text { by a rheumatology } \\
\text { specialist within } 3 \\
\text { weeks after referral. }\end{array}$ & $\begin{array}{l}\text { The number of } \\
\text { patients with } \\
\text { a suspicion of } \\
\text { axSpA that is } \\
\text { assessed by a } \\
\text { rheumatologist } \\
\text { within } 3 \text { weeks } \\
\text { after referral. }\end{array}$ & $\begin{array}{l}\text { The number of } \\
\text { patients with } \\
\text { suspicion of axSpA } \\
\text { referred to a } \\
\text { rheumatologist. }\end{array}$ & $\begin{array}{l}7.2 \pm 2.5 \\
\text { second vote: } \\
86.7 \%\end{array}$ & 69.6 \\
\hline QS3 & Assessment & $\begin{array}{l}\text { Patients with } \\
\text { suspicion of } \\
\text { axSpA have } \\
\text { their diagnostic } \\
\text { work-up } \\
\text { completed } \\
\text { within } 2 \\
\text { months. }\end{array}$ & $\begin{array}{l}\text { Timely diagnostic work-up by } \\
\text { a rheumatologist is needed to } \\
\text { ensure correct diagnosis and to } \\
\text { achieve better long-term outcomes } \\
\text { and improve their quality of life. } \\
\text { Diagnostic work-up includes } \\
\text { identification of SpA variables, } \\
\text { laboratory and imaging results. } \\
\text { Diagnostic work-up should be } \\
\text { completed within } 2 \text { months after first } \\
\text { appointment. }\end{array}$ & $\begin{array}{l}\text { Evidence of local } \\
\text { arrangements } \\
\text { including sufficient } \\
\text { number of } \\
\text { rheumatologists and } \\
\text { facilities and access } \\
\text { to facilities in the } \\
\text { given timeframe to } \\
\text { ensure that patients } \\
\text { with suspicion } \\
\text { of axSpA have a } \\
\text { diagnostic work-up } \\
\text { within } 2 \text { months after } \\
\text { first appointment by } \\
\text { a rheumatologist. }\end{array}$ & $\begin{array}{l}\text { The number of } \\
\text { patients with } \\
\text { a suspicion of } \\
\text { axSpA, in whom } \\
\text { a diagnostic } \\
\text { work up was } \\
\text { completed within } \\
2 \text { months after } \\
\text { first appointment. }\end{array}$ & $\begin{array}{l}\text { The number of } \\
\text { patients with } \\
\text { suspicion of } \\
\text { axSpA seen for the } \\
\text { first time by the } \\
\text { rheumatologist } \\
\text { more than } 2 \\
\text { months ago. }\end{array}$ & $8.5 \pm 2.0$ & 89.6 \\
\hline
\end{tabular}

ASAS, Assessment of SpondyloArthritis International Society; axSpA, axial spondyloarthritis; NRS, numerical rating scale.

exist within each country and between different countries, and the ASAS-QS may serve as a tool for assessing, delivering and demanding optimal care for patients with axSpA in any country. QS are intended to help organisations improve quality of care and to monitor service improvements by supporting comparison of current performance. All ASAS-QS are achievable in daily care in an optimised situation and intend to minimise variation in quality of care. It is emphasised that ASAS is well aware that all QS are ideal visions of an optimal care provision which may currently not be realistic in many countries. ASAS-QS are aspirational but they may guide a wide range of purposes both locally and nationally. For example, people using services, careproviders and the public can use the QS to identify components of a high-quality service that is achievable.

Assessing quality of care provided to patients with rheumatic diseases is challenging because various areas need to be improved 
Table 2 Quality standards (QS) for axial spondyloarthritis, treatment

\begin{tabular}{|c|c|c|c|c|c|c|c|c|}
\hline No & Domain & Statement & Rationale & $\begin{array}{l}\text { Quality measure, } \\
\text { category structure }\end{array}$ & $\begin{array}{l}\text { Quality } \\
\text { measure, } \\
\text { category } \\
\text { process, } \\
\text { numerator }\end{array}$ & $\begin{array}{l}\text { Quality } \\
\text { measure, } \\
\text { category } \\
\text { process, } \\
\text { denominator }\end{array}$ & $\begin{array}{l}\text { Level of } \\
\text { agreement, NRS } \\
0-10\end{array}$ & $\begin{array}{l}\text { Agreement } \\
\text { (NRS } \geq 7 \text { by } \\
75 \% \text { of ASAS } \\
\text { members) }\end{array}$ \\
\hline QS4 & Monitoring & $\begin{array}{l}\text { Disease activity } \\
\text { of patients } \\
\text { with aSpA is } \\
\text { monitored } \\
\text { under the } \\
\text { supervision of a } \\
\text { rheumatologist } \\
\text { with validated } \\
\text { composite } \\
\text { scores at least } \\
\text { every } 6 \text { months. }\end{array}$ & $\begin{array}{l}\text { Assessment of disease activity is of } \\
\text { importance because of the correlation } \\
\text { between clinical disease activity } \\
\text { and syndesmophyte formation and } \\
\text { between disease activity, function } \\
\text { and health-related quality of life. } \\
\text { Monitoring of disease activity by } \\
\text { a rheumatologist (which implies } \\
\text { the rheumatology team including } \\
\text { physicians, nurses, other health } \\
\text { professionals) is required because of } \\
\text { multifaceted and ambiguous clinical } \\
\text { symptoms of disease activity such } \\
\text { as pain and disability. Assessment } \\
\text { of disease activity using ASDAS } \\
\text { is recommended. Repeating the } \\
\text { assessment at regular intervals will } \\
\text { ensure that the treatment of patients } \\
\text { with axSpA is adapted when they } \\
\text { need it. }\end{array}$ & $\begin{array}{l}\text { Evidence of local } \\
\text { arrangements to } \\
\text { ensure that patients } \\
\text { with aSpA have an } \\
\text { assessment with } \\
\text { validated composite } \\
\text { scores at least every } \\
6 \text { months. }\end{array}$ & $\begin{array}{l}\text { The number } \\
\text { of patients } \\
\text { diagnosed with } \\
\text { axSpA more } \\
\text { than } 6 \text { months } \\
\text { ago in whom } \\
\text { disease activity } \\
\text { was monitored } \\
\text { with validated } \\
\text { composite } \\
\text { scores at least } \\
\text { every } 6 \text { months. }\end{array}$ & $\begin{array}{l}\text { The number } \\
\text { of patients } \\
\text { diagnosed with } \\
\text { axSpA more than } \\
6 \text { months ago. }\end{array}$ & $8.0 \pm 2.2$ & 81.7 \\
\hline QS5 & Disease control & $\begin{array}{l}\text { In patients } \\
\text { with axSpA } \\
\text { and active } \\
\text { disease despite } \\
\text { conventional } \\
\text { therapy, } \\
\text { treatment } \\
\text { escalation with } \\
\text { biological drugs } \\
\text { is discussed. }\end{array}$ & $\begin{array}{l}\text { Treatment escalation is important } \\
\text { to achieving disease control, which } \\
\text { ideally results in remission or a low } \\
\text { disease activity state, and therefore } \\
\text { lower disease impact on functioning } \\
\text { and everyday living. Patients who } \\
\text { have high disease activity despite } \\
\text { conventional therapy should discuss } \\
\text { the use of biological drugs with } \\
\text { their rheumatologist, taking patient } \\
\text { profile, cost and access to biologicals } \\
\text { into account. The } 2016 \text { update of } \\
\text { the ASAS-EULAR management } \\
\text { recommendations for axSpA provides } \\
\text { criteria for recommending use of } \\
\text { biologicals in patients with axial } \\
\text { disease and high disease activity. The } \\
\text { choice of intervention should be a } \\
\text { joint decision between patient and } \\
\text { rheumatologist. }\end{array}$ & $\begin{array}{l}\text { Evidence of local } \\
\text { arrangements to } \\
\text { ensure that patients } \\
\text { with axSpA and } \\
\text { active disease } \\
\text { despite conventional } \\
\text { therapy are offered } \\
\text { biologicals according } \\
\text { to the ASAS } \\
\text { recommendations to } \\
\text { improve the chance } \\
\text { of remission or low } \\
\text { disease activity in } \\
\text { the future. }\end{array}$ & $\begin{array}{l}\text { The number } \\
\text { of patients } \\
\text { with axSpA } \\
\text { and active } \\
\text { disease despite } \\
\text { conventional } \\
\text { therapy } \\
\text { in whom } \\
\text { treatment with } \\
\text { biologicals has } \\
\text { been discussed. }\end{array}$ & $\begin{array}{l}\text { The number of } \\
\text { patients with } \\
\text { axSpA and active } \\
\text { disease despite } \\
\text { conventional } \\
\text { therapy. }\end{array}$ & $9.2 \pm 1.5$ & 94.8 \\
\hline QS6 & $\begin{array}{l}\text { Treatment, } \\
\text { non-pharma }\end{array}$ & $\begin{array}{l}\text { Patients with } \\
\text { axSpA are } \\
\text { informed about } \\
\text { the benefits of } \\
\text { regular exercise. }\end{array}$ & $\begin{array}{l}\text { Physical activity should be an integral } \\
\text { part of standard care throughout the } \\
\text { course of disease in patients with } \\
\text { axSpA. It is important that patients } \\
\text { with axSpA are given information } \\
\text { about benefits of regular exercise } \\
\text { to reduce pain and stiffness and } \\
\text { improve cardiorespiratory fitness and } \\
\text { by doing so, also reducing the risk for } \\
\text { cardiovascular disease. Actively raising } \\
\text { the usefulness of exercising regularly } \\
\text { will support patients in improving } \\
\text { functioning and maintaining quality } \\
\text { of life. }\end{array}$ & $\begin{array}{l}\text { Evidence of local } \\
\text { arrangements to } \\
\text { encourage patients } \\
\text { with axSpA to } \\
\text { exercise on a regular } \\
\text { basis. }\end{array}$ & $\begin{array}{l}\text { The number } \\
\text { of patients } \\
\text { diagnosed with } \\
\text { axSpA who are } \\
\text { informed about } \\
\text { the benefits of } \\
\text { regular exercise. }\end{array}$ & $\begin{array}{l}\text { The number } \\
\text { of patients } \\
\text { diagnosed with } \\
\text { axSpA. }\end{array}$ & $9.5 \pm 0.9$ & 98.3 \\
\hline
\end{tabular}

ASAS, Assessment of SpondyloArthritis International Society; ASDAS, Ankylosing Spondylitis Disease Activity Score; axSpA, axial spondyloarthritis; NRS, numerical rating scale.

worldwide. For example, the number of rheumatologists for a certain population, healthcare utilisation for groups of patients with rheumatological disorders and appropriate outcome measures are some of the many issues which are also relevant for patients with axSpA. Moreover, scientific evidence might be scarce for the identified key areas for quality improvement. This was the case for example, when phrasing the ASAS-QS topic 'referral'. Whereas the delay in diagnosis is clearly an important gap in daily care experienced by many patients with axSpA, the challenge faced by the ASAS-QS group was twofold: (1) systems of referral to specialists vary worldwide and (2) evidence for the optimal time period is lacking. However, the ASAS-QS group was convinced that given a specific timeframe instead of phrasing like 'timely or immediately' is needed to force substantial decrease in diagnostic delay. Moreover, the concept of QS requires the QS to be measurable (quantifiable). ${ }^{15}$ Hence, the 


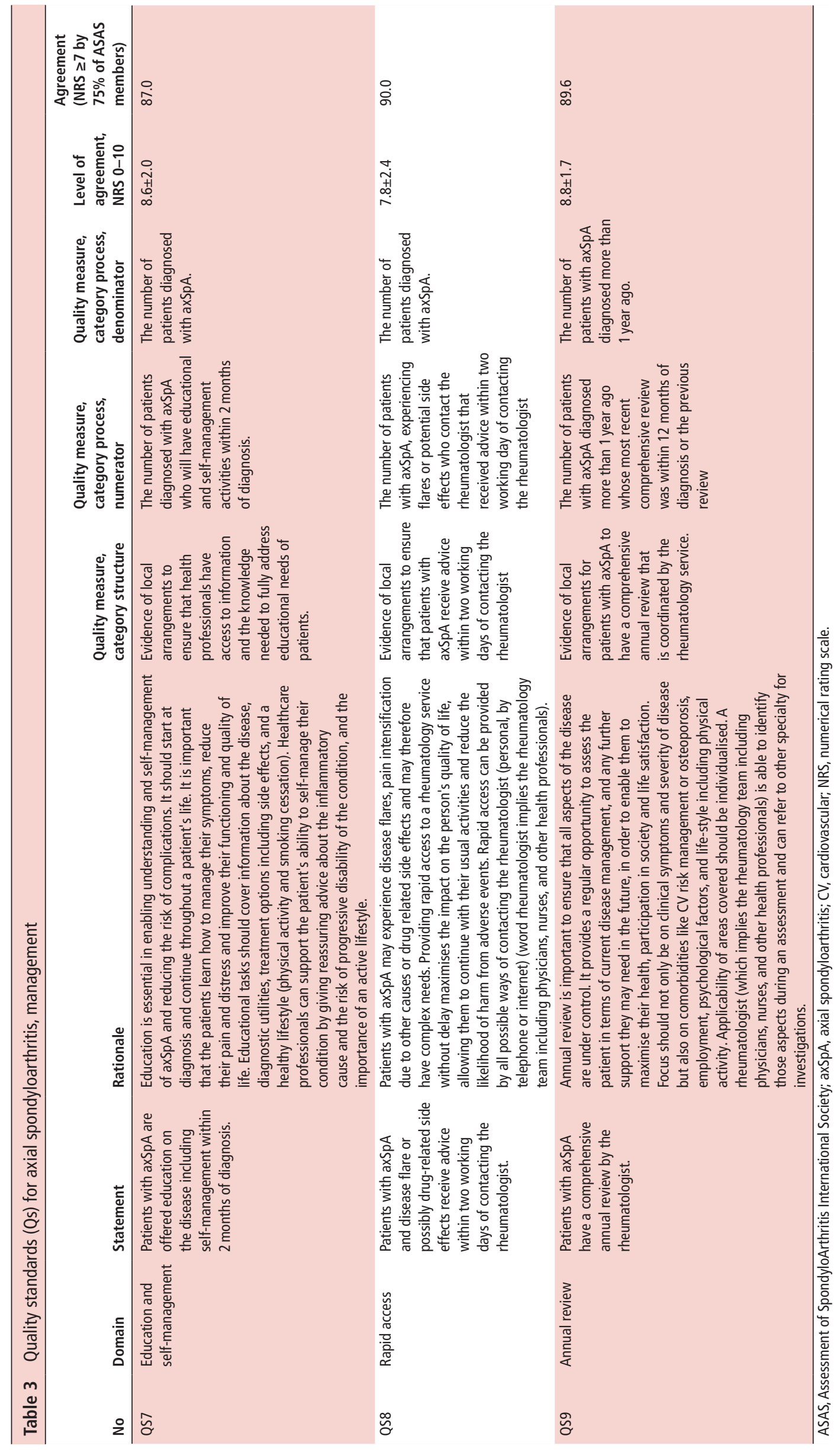


intention of the referral QS (QS1) is to reach high quality of care and therefore, enhance the practice of referrals to rheumatologists in patients with 'suspicion of axSpA' taking into account that rheumatologists are the medical specialists primarily responsible for diagnosing and treating patients with axSpA. There is ample evidence that recognition of axSpA can be optimised by an adequate preselection of patients to be referred to the rheumatologist based on combination of different parameters such as inflammatory back pain, HLA-B27 or sacroiliitis. ${ }^{17}$ An obvious consideration is whether the ASAS-QS could be applied to other rheumatic diseases since many of the concepts utilised in these QS are relevant to other rheumatic conditions. However, three arguments may be against operationalisation of ASAS-QS into a different context: (1) axSpA is still less recognised than other inflammatory rheumatic diseases, has less recognisable features and takes longer time to diagnose, (2) ASAS is a group of experts in the field of spondyloarthritis and each step of the methodology relates explicitly to patients with SpA, and (3) the ASAS-QS group might not be representative for other rheumatic diseases. ASAS group apprehend that utilisation of disease-specific QS in a wider context might reduce the impact of such QS. Therefore, we suggest that ASAS-QS cannot be extrapolated to other rheumatic diseases directly, but may form a template for other diseases. QS are different from recommendations or guidelines. Recommendations imply evidence-based actions that should be done in order to optimally diagnose and treat the disease. Usually, every important aspect of the disease is covered. QS are measurable constructs relating to specific aspects of the disease where there is unwarranted performance variation at the community level. Moreover, quality standards are going beyond the intention of recommendations because they intend to measure improvement in quality of care. Yazdany et al showed in a communitybased cohort that following systemic lupus erythematosus (SLE) quality measures was significantly protective against increased disease damage (Brief Index of Lupus Damage adjusted OR 0.4, $95 \%$ CI 0.4 to 0.7$).^{18}$

Our experience in developing disease-specific QS within an international group of $\mathrm{SpA}$ experts showed that the endorsement of QS sets into national public health domains can be ambitious. After the approval of QS 1 (referral) and QS 2 (time to specialist) failed in the initial voting round by the ASAS community, intensive discussion, explanation and evaluation followed, resulting in an approval of the initial wording of QS 1 and 2. We learnt from that experience that implementation strategies must be accompanied at national levels by education about the meaning of QS in order to specify the intention of the QS: optimise quality of care at a community level instead of describing current practice of daily care.

In fact, implementation is a crucial aspect in the process of using the ASAS-QS at a national level. When implementing QS at a national level, several components such as data source, target population and reporting period have to be defined nationally prior to analysing QS in an individual country. ${ }^{19} \mathrm{~A}$ separate project is usually necessary for a successful implementation. ASAS did not decide on specific implementation strategies but leave it up to the national ASAS members. A major strength of this ASAS initiative is the participation of $\mathrm{SpA}$ experts from all over the world including other health professionals (physiotherapists), and patients with axSpA. Thus, we think that inclusion of a variety of stakeholders adds to the representativeness of the ASAS-QS set. Another strength is the restriction to the most important areas in which variation in quality of care has been identified by the panel. Focusing on five key areas (referral, rheumatology assessment, treatment, education/self-management and comorbidities) increases the probability to induce a substantial improvement in quality of care. A limitation of our work is that we were not able to test the feasibility of the ASAS-QS in clinical practice worldwide. This is an important issue since previous research in the field of QS operationalised as indicators for rheumatoid arthritis showed that less than 50\% of information was available for measuring quality indicators in registries. ${ }^{20}$

With the help of the ASAS-QS one can focus on which resources and processes are needed to deliver high quality of care at the community level, thereby reducing significant healthcare disparities among populations and across regions. As indicated earlier, NICE published recently a quality assessment tool for patients with axSpA which was developed in parallel to the ASAS-QS set. ${ }^{13}$ None of the ASAS members participated in NICE guidance and no ideas were exchanged between both groups. Interestingly, areas addressed are quite similar and topics covered in both sets are the domains of referral and assessment as well as the importance of exercise and education about the disease.

The ASAS-QS set is not intended to replace other methods to improve quality of care. Furthermore, other methods, such as medical education, effective use of information technologies, and the development of evidence-based guidelines and practice recommendations, should complement the implementation of the ASAS-QS set. The proposed ASAS-QS for axSpA do not provide a comprehensive service specification. They rather define priority areas for quality of care improvement. The ASAS-QS should now be implemented at a national level for local quality improvement.

\section{Author affiliations}

${ }^{1}$ Rheumatology, Rheumazentrum Ruhrgebiet, Ruhr-University Bochum, Herne, Germany

${ }^{2}$ Amsterdam Rheumatology Center, AMC, Amsterdam, The Netherlands

${ }^{3}$ Rheumatology, Zuyderland MC, Heerlen, The Netherlands

${ }^{4}$ Rheumatology, Leiden University Medical Center, Leiden, The Netherlands

${ }^{5}$ Internal Medicine and Rheumatology, Klinikum Bielefeld Rosenhöhe, Bielefeld, Germany

${ }^{6}$ Division of Rheumatology, Department of Medicine, David Geffen School of Medicine, Los Angeles, California, USA

${ }^{7}$ Department of Medicine, Division of Rheumatology, Celal Bayar University School of Medicine, Manisa, Turkey

${ }^{8}$ Internal Medicine, Division of Rheumatology, Maastrich University Medical Center, Maastricht, The Netherlands

${ }^{9}$ Care and Public Health Research Institute (CAPHRI), Maastricht, The Netherlands

${ }^{10}$ Rheumatology, Private Practice, Berlin, Germany

${ }^{11}$ Rheumatology, Ghent University Hospital, Ghent, Belgium

${ }^{12}$ VIB Inflammation Research Center, Ghent, Belgium

${ }^{13}$ Hopital Cochin, Rheumatology, Université Paris Descartes, Paris, France

${ }^{4}$ INSERM (U1153): Epidémiologie Clinique et Biostatistiques, PRES Sorbonne ParisCité, Paris, France

${ }^{15}$ Institut Pierre Louis d'Epidémiologie et de Santé Publique (iPLESP), UMR S 1136, Sorbonne Universite, Paris, France

${ }^{16}$ APHP, Rheumatology department, Hopital Universitaire Pitie Salpetriere, Paris, France

${ }^{17}$ Patient Research Partner, Amsterdam, The Netherlands

${ }^{18}$ MRC Centre for Neuromuscular Diseases, University College London, London, UK ${ }^{19}$ Rheumatology, University College London Centre for Rheumatology, London, UK

${ }^{20} \mathrm{NIHR}$ Leeds Biomedical Research Centre, Leeds Teaching Hospitals Trust and Leeds Institute of Rheumatic and Musculoskeletal Disease, University of Leeds Faculty of

Medicine and Health, Leeds, UK

${ }^{21}$ Rheumatology, Hopital Cochin, paris, France

${ }^{22}$ Department of Rheumatology, University Hospital La Paz, IdiPaz, Madrid, Spain

${ }^{23}$ School of Health Professions, Institute of Physiotherapy, Zurich University of

Applied Sciences, Winterthur, Switzerland

${ }^{24}$ Faculdade de Medicina da Universidade de São Paulo e Hospital das Clínicas da

Faculdade de Medicina da Universidade de São Paulo, Sao Paulo, Brazil

${ }^{25}$ Department of Internal Medicine A, Bnai Zion Medical Center, Technion, Haifa, Israel

${ }^{26}$ Department of Internal Medicine and Pediatrics, Ghent University Faculty of Medicine and Health Sciences, Gent, Belgium

${ }^{27}$ Reade, Centre for Rehabilitation and Rheumatology, Amsterdam, The Netherlands 
${ }^{28}$ Patient Research Partner, Huenxe, Germany

Correction notice This article has been corrected since it published Online First. The author, Merryn Jongkees, name has been corrected.

Twitter Nurullah Akkoc @nurullahakkoc, Philippe Carron @PhilippeCarron and Pedro M Machado @pedrommcmachado

Acknowledgements We are thankful to our patient partners Luc Ghekiere and Monique Wouters who supported the meeting in Ghent, Belgium in September 2016, and patient partners from Belgium, France, Germany, Israel, the Netherlands, Portugal, Spain, Turkey, USA and UK who participated in the web-based surveys.

Contributors JB, UK, RBML, MR, DvdH, MHW designed the study. All authors have contributed to the development of the quality standard set by participating in the meetings. UK and JB contributed to data management and analysis of the webbased surveys. JB, UK, RBML, MR, DvdH, MHW draft the publication and all authors were involved in revising the article critically. The final version of the report was seen and approved by all authors.

Funding This study was funded by Assessment of SpondyloArthritis international Society (ASAS). PMM is supported by the National Institute for Health Research (NIHR) University College London Hospitals (UCLH) Biomedical Research Centre (BRC). HMO is supported by the National Institute for Health Research (NIHR) Leeds Biomedical Research Centre (BRC).

Competing interests $A B$ received research grants to her department from Abbvie and Celgene and honoraria for lectures or consulting fees form UCB, Janssen, Sandoz, Novartis and Eli-Lilly. JB: honoraria for talks, advisory boards, paid consultancies and grants from studies from Abbvie, Amgen, BMS, Boehringer, Celgene, Celltrion, Centocor, Chugai, EBEWE Pharma, Medac, MSD (ScheringPlough), Mundipharma, Novartis, Pfizer (Wyeth), Roche, Sanofi-Aventis, UCB. PC: honoraria for talks, advisory boards, paid consultancies from Celgene, MSD (Schering-Plough), Novartis, Pfizer (Wyeth), Roche, Sanofi-Aventis, UCB. MD: honoraria for lectures and advisory board meetings for Pfizer, Abbvie, Merck, UCB, Lilly, Novartis. LG research grants: Pfizer, UCB, Lilly, Bristol-Myers Squibb; honoraria for lectures and advisory board meetings from AbbVie, Amgen, Biogen, Celgene, Janssen, Lilly, MSD, Novartis, Pfizer, Sandoz, Sanofi-Aventis, UCBU. UK: received grant and research support and consultancy fees from AbbVie, Biogen, Chugai, Eli Lilly, Grünenthal, Janssen, MSD, Novartis, Pfizer, Roche and UCB. RBML: honoraria for lectures and advisory board meetings for AbbVie, Celgene, Galapagos, Janssen, Lilly, Novartis, Pfizer, UCBP. PMM has received consulting/speaker's fees from Abbvie, BMS, Celgene, Janssen, MSD, Novartis, Pfizer, Roche and UCB. HM-O: grants from Janssen, Novartis. Speaking, honoraria from Abbvie, Celgene, Eli-Lilly, Janssen, Novartis, Pfizer and UCB. AM: honoraria for lectures and advisory board meetings for AbbVie, BMS, Janssen, MSD, Novartis, Sanofi, Pfizer and UCB.VN-C: consultancy/ speaker/research grants from: Abbvie, BMS, Lilly, MSD, Novartis, Pfizer, Roche, UCB. educational/research grants: SAR, SER, SORCOM, EULAR, ASAS. MR: honoraria for presentations or advisory board meetings from Abbvie, Celgene, BMS, Janssen, Lilly, MSD, Novartis, Pfizer, UCB. PS-B: honoraria for presentations or advisory board meetings from Abbvie, Boehringer Ingelheim, Janssen, Novartis, UCB. GS: honoraria for lectures and/or advisory board meetings from Abbvie, Lilly, Novartis, Sanofi, Roche. DvdH: consulting fees AbbVie, Amgen, Astellas, AstraZeneca, BMS, Boehringer Ingelheim, Celgene, Daiichi, Eli-Lilly, Galapagos, Gilead, Glaxo-Smith-Kline, Janssen, Merck, Novartis, Pfizer, Regeneron, Roche, Sanofi, Takeda, UCB Pharma. Director of Imaging Rheumatology AvT received research grants from Pfizer, Abbvie, UCB, Novartis and Biogen and consulting fees from Novartis, Jansen-Cilag, Pfizer, MW: consulting fees from Novartis, Lilly, UCB.

Patient and public involvement statement Patient partners supported the study at each stage of the project. Patient partners collaborated with us for the design of the project, the informational material to support the web-based surveys, and were actively involved in the identification of the key areas for quality improvement and the phrasing of the quality statements. Patients who participated in the web-based surveys helped us to understand the gaps in quality of care from the patient's perspective. At the end of the study, the patient partners commented on the phrasing of the quality rationale and measure as well as a critical revision of the manuscript.

Patient consent for publication Not required.

Provenance and peer review Not commissioned; externally peer reviewed.
Data availability statement All data relevant to the study are included in the article or uploaded as supplementary information.

Open access This is an open access article distributed in accordance with the Creative Commons Attribution Non Commercial (CC BY-NC 4.0) license, which permits others to distribute, remix, adapt, build upon this work non-commercially, and license their derivative works on different terms, provided the original work is properly cited, appropriate credit is given, any changes made indicated, and the use is non-commercial. See: http://creativecommons.org/licenses/by-nc/4.0/.

\section{ORCID iDs}

Uta Kiltz http://orcid.org/0000-0001-5668-4497

Désirée van der Heijde http://orcid.org/0000-0002-5781-158X

Laure Gossec http://orcid.org/0000-0002-4528-310X

Pedro M Machado http://orcid.org/0000-0002-8411-7972

Anna Molto http://orcid.org/0000-0003-2246-1986

\section{REFERENCES}

1 Sieper J, Poddubnyy D. Axial spondyloarthritis. Lancet 2017;390:73-84.

2 Putrik P, Ramiro S, Kvien TK, et al. Inequities in access to biologic and synthetic DMARDs across 46 European countries. Ann Rheum Dis 2014;73:198-206.

3 Nikiphorou E, van der Heijde D, Norton $\mathrm{S}$, et al. Inequity in biological DMARD prescription for spondyloarthritis across the globe: results from the ASAS-COMOSPA study. Ann Rheum Dis 2018;77:405-11.

4 Sørensen J, Hetland ML, All Departments of Rheumatology in Denmark. Diagnostic delay in patients with rheumatoid arthritis, psoriatic arthritis and ankylosing spondylitis: results from the Danish nationwide DANBIO registry. Ann Rheum Dis 2015;74:e12.

5 Feldtkeller E, Khan MA, van der Heijde D, et al. Age at disease onset and diagnosis delay in HLA-B27 negative vs. positive patients with ankylosing spondylitis. Rheumatol Int 2003:23:61-6.

6 Mennini FS, Viti R, Marcellusi A, et al. Economic evaluation of spondyloarthritis: economic impact of diagnostic delay in Italy. Clinicoecon Outcomes Res 2018;10:45-51.

7 Initiative IHCQ. Crossing the quality chasm. The IOM Health Care Quality Initiative, 2006.

8 Solomon DH, Gabriel SE. Quality measures 101: what every rheumatologist should know. Clin Exp Rheumatol 200;25:18-21.

9 Wilson BA, Cooper M, Barber CEH. Standards of care for inflammatory arthritis: a literature review. Semin Arthritis Rheum 2017:47:22-8.

10 Barber CEH, Marshall DA, Mosher DP, et al. Development of system-level performance measures for evaluation of models of care for inflammatory arthritis in Canada. J Rheumatol 2016;43:530-40.

11 Petersson IF, Strömbeck B, Andersen L, et al. Development of healthcare quality indicators for rheumatoid arthritis in Europe: the eumusc.net project. Ann Rheum Dis 2014;73:906-8.

12 Mikuls TR, MacLean CH, Olivieri J, et al. Quality of care indicators for gout management. Arthritis Rheum 2004;50:937-43.

13 McAllister K, Goodson N, Warburton L, et al. Spondyloarthritis: diagnosis and management: summary of NICE guidance. BMJ 2017;356.

$14 \mathrm{NIfHaCE}$. Quality Standards process guide, 2016

15 Donabedian A. Methods for deriving criteria for assessing the quality of medical care. Med Care Rev 1980:37:653-98.

16 van der Heijde D, Ramiro S, Landewé R, et al. 2016 update of the ASAS-EULAR management recommendations for axial spondyloarthritis. Ann Rheum Dis 2017;76:978-91.

17 Poddubnyy D, van Tubergen A, Landewe R, et al. Assessment of spondyloarthritis international S. development of an ASAS-endorsed recommendation for the early referral of patients with a suspicion of axial spondyloarthritis. Ann Rheum Dis 2015:74:1483-7.

18 Yazdany J, Trupin L, Schmajuk G, et al. Quality of care in systemic lupus erythematosus: the association between process and outcome measures in the lupus outcomes study. BMJ Qual Saf 2014;23:659-66.

19 Suter LG, Barber CE, Herrin J, et al. American College of rheumatology white paper on performance outcome measures in rheumatology. Arthritis Care Res 2016:68:1390-401.

20 Navarro-Compán V, Smolen JS, Huizinga TWJ, et al. Quality indicators in rheumatoid arthritis: results from the Meteor database. Rheumatology 2015:54:1630-9. 